Kholov Vohid Yusupovich

Junior Research Fellow of the Institute of History, Lecturer at Turin Polytechnic University in Tashkent

v.kholov@polito.uz

\title{
The Issue of Central Asia in the Works of European Researchers and the Study Medical Condition of the Area
}

\begin{abstract}
The article analyses the reasons of the development of Central Asia Studies in English speaking literature. There has been categorized authors' works due to their character and the purposes of the expeditions and travels. Besides, medical condition in the area, the methods of treatment, the integration of local medicine with European medicine have been highlited in the article.
\end{abstract}

Key words: Area studies, Geographical Societies, foreign researchers and travelers, medicine, rishta, eye deseases, apothecaries, doctors.

\section{Introduction}

Area Studies is one of the branches of researches that has developed for thousands of years. In this field of study, Central Asia has been the core of studies in different periods. Early historical notes about Central Asia in found in Greek, Persian and Chinese literatures of ancient times and this tradition kept developing in further historical periods in Arabic sources during Arabic civilization or called as Central Asian renaissance. Coming to XVIII-XIX centuries, researches in exploring Central Asia reached its peak growing popularity among scholars, travelers and politicians. As professor D. Ziyaeva mentioned, there were not written and published so many books, as well as articles on Central Asia in other periods as those written in XIX - early XX centuries [Ziyaeva: 27].

\section{Main Part}

The main factors of this issue can be judged due to high interest to Pamir and Tien-shan mountains, myths that were spread about Central Asian parts and of course geopolitical and economic interests of other countries. On this occasion, Royal Geographical society of Great Britain, Russian Imperial Geographical Society, Annales School of France, American Geographical Society and the 
geographical and other societies of other countries conducted vast majority of expeditions on Central Asia [8].

The increase of political, territorial and economic interests of Great Britain and her competition with Russian Empire provided the growth of the volume of scientific expeditions and researches in Central Asia. Consequently, this led to the preparation and publication of scientific articles and books in British and American societies. These works have become very helpful to disclose the history of Central Asia, its climate, flora, fauna, medicine, irrigation, agriculture, social and economic issues, culture and other problems in XIX - early XX centuries.

Due to the character and nature of works and the affiliation of the authors, the works written in English in given period can be classified into groups as follow:

The researches held for British interests and military purposes can be included in the first group. This is seen how thoroughly they studied the geography of the area. For example, W. Moorcroft, G. Trebeck, A. Burns, J. Abbot, Ch. Stoddart, Conolly, R. Shakespeare, H.A. Vambery, F. Burnaby, H. Rawlinson can be given in this list who were shown as reconnoiters or spies by Charles Marvin in his work.

The second group includes the works published by the members of different scientific societies, foundations and governmental organizations. Here can be included H. Lansdell, Mc Gahan, Delmar Morgan, Ole Olufsen, R. Pumpelli, A. Meakin, G. Curtis and etc. Their works mostly give information about ethnology, history, archaeology, flora, fauna, medicine and other spheres.

The third group covers the works of state representatives who visited Central Asia as officials and took high ranks after their Central Asian trip. G.N. Curzon and E. Schuyler are the best examples of this.

All the works published by European authors were written in accordance with the experiences of the authors that they gained in the area while they were travelling, they information they collected by inquiring from natives, the works of Russian authors, the manuscripts written in Central Asia, statistical data of the 
government and local bodies and the works written and published before they had visited the area. Representing colossal information, they depict medicine, medical condition, ailments and their treatment, curing methods of local and migrant doctors and apothecaries.

During the study of the medical history of the researched period, it is possible to see the diversity in the area. Especially, the treatment methods that were local and appeared with Russian, as well as diseases that appeared with Russians, problems with treatment, and similarities are seen in the diversity. According to E. Schuyler, the first treatment of local doctors was to check the patient's overall appearance and temperament. The most widely used book in medicine was Tuhfatul Muminin. The doctor summarized the patient's symptoms with the patient's client and took the medication from the pouch or luggage to the patient, giving the patient the usual instructions on his diet [Schuyler:149]. The medicines used by Central Asian doctors are usually very simple and mainly plant material, which use a small amount of animal and mineral substances. They are usually in the form of powder or dripping, allowing the patient to give different substances to the patient and to prepare for him when the need arises. It not only made it easier for a physician to help but also helped to avoid the suspicion that the patient was poisoned. Annette Meakin noted that among doctors who studied in Bukhara had higher status in the society [Meakin:167].

The medical condition of the 19th and beginning of the 20th century, especially traditional and new forms of treatment, can be seen in curing diseases spread at that time. In particular, local people often used traditional methods of treatment to prevent deseaes, and their effectiveness in some respects was reflected in historical works, especially in western sources. Although the spread of the plague in the east was rarely seen, there were some measures and experience to refrain it from spreading. An example of this can be seen in the case of plague spreading near Samarkand and preventing its spread to other vicinities.

Almost all foreign researchers and travellers wrote about medical conditions, diseases and their treatment methods in the region which shows the transformation 
the diagnosis and treatment of the disease. Most studies show that health care was mainly provided by bleeding doers, dentists, healthcare workers, mullahs and rishta drawers, and some health services were mostly conducted outdoors. Despite this, the analysis of foreign literature shows that in the second half of the 19th century there were medical institutions in the region. For instance, H. Lansdell, O. Olufsen noted about local treatment places, dispanceries, and Russian built hospitals [Lansdell:147].

During the studied period, medical services were provided by both local and European (Russian) doctors. The newcomers in the area rejected neither local nor European treatment while local people (mostly Muslims) initially did not pay attention to the advanced European skills of curing rejecting European doctors' service. For example, in Bukhara, the local population rarely allowed them to be examined by a European doctor. The women never did this. Because it was considered contrary to Islamic law. However, the views of nomadic people differed significantly from the urban population. The reason for this is that nomads were generally not as strong as local residents. That was the reason why nomads had a lot of appeals to European doctors.

Despite the fact that European doctors did not refuse to serve the local population, the local population were not in favour of their medical care. This is not explained by their suspicion of European medicine, but rather, in the future, to prevent possible problems, but because they feared that other inconveniences would arise from it; an infidel was namely always considered to be on too friendly terms with Satan (Shaitan), and some evil is sure to be connected with his wares. In the towns the spiritual mullahs do what they can to prevent the sick from consulting the European or applying for his medicine, the native apothecaries and medicine-men doing their best too, of course, out of regard to their business. O. Olufshennig writes that Bukhara's most cultivated classes, who spent months and years with him, whom he cured typhus and fever had, but patients returned to mullahs when the illness returned [Olufsen: 442]. Mulla ordered them to give them a piece of paper and place them in the place where they had been infected, and 
instead of using the ointment, they ordered a piece of cloth to cover the tree and then put a piece of cloth into a tree or put it in a saint's tomb.

In Central Asian medicine, it was thought to be uncertain about the surgical practice and that it was impossible to perform any amputation. For, for example, they thought that if the foot was cut off, it would not stand on the Day of Judgement. People were not allowed to use knife like tools in the Arabian medicine [Olufsen 441].

Rishta wass one of the most common diseases in the Turkestan, Bukhara emirate and Khiva Khanate, which had long been reported in sources. There are different myths about the origin of this disease, one of which is associated with prophet Job and one of Balkhs rulers. According to sources, even Ibn Sino gave his instructions on treating this disease. In addition to local and Russian explorers, tourists, researchers, expedition members from the West to Central Asia provided information on the disease, the methods of its treatment and its complications. O.Olufsen notes that this epidemic was the most widespread disease in Bukhara, whose $1 / 3$ of the population were suffering from this disease. I. Azizov notes that in Jizzakh, this disease caused a wider threat comparing to other regions [Azizov:234]. One can find information that even people visiting Bukhara for the first time knew aout the desease in advance and it was amazing if visitors did not know it. Rishta was mentioned by diferent names in foreign literatures. For example, in the 16th century, Jenkinson called it desiderius, and E. Schuyler "Guinea-worm" (filaria medinensis) [Shuyler:147], O. Olufsen called "filaria medinensis" or "filaria bokhariensis" [Olufsen:442]. H Lansdell noted that he had read about it in J. Wolf's book, and this disease was common in Bukhara, Karshi, Kattakurgan and Jizzakh [Lansdell:146]. However, in most western studies, the ailment was mentiones as rishta.

At that time, biologists, parasitologists, bacteriologists and doctors conducted a series of investigations to explore the origin of the disease. As a result, stagnant water resouvoirs provide more favorable climate for its reproduction, especially in the contaminated waters, and their proliferation and spread accelerate. 
Despite the fact that the water in the stagnant water basins was discovered by a microscope, worm itself was not yet been discovered in the water [Olufsen: 442]. However, this study did not influence the conclusions about abovementioned factors.

The fact that Rishta was not found in populations living in ponds of water might also lead researchers to come to such conclusion. This disease was common in such cities as Jizzakh and Bukhara, where pools were filled with water and then used for long periods which was a cause for illness. Therefore, water and food products were first boiled and then used and recommended as the most effective way to protect against the disease. Even the desease appeared not only water consumed but when hands and face were also washed.

The condition of Rishta in organisms is almost identical in the researches. For example, E. Schuyler supposed that infusrian [Shuyler:147] caused its development, and it might come in a body while drinking filthy or contaminated water demonstrating itself in about a year, it begins to grow in the form of a white worm and showing traces on one of the legs. Olufsen noted that the egg slowly develops under his skin and looks like a long cord with cylinder shaped head. In some parts of the body, especially in the legs, itching begins (if the disease in a head, it is very dangerous), red spots appear on the affected area, the part where its head is very painful and reasining fever. Effective treatment of this disease was known in Bukhara than in other regions, and most of these patients addressed to the hairdresser. The hairdresser cut the abscess and squeezed the head of the worm with a small instrument on which he unrolled the worm like a roll of twine. $\mathrm{H}$ Lansdell described the practice and said that rishta was drawn by right hand hand fingers and injured part was squeezed out by left hand fingers and the operation lasted for 1-5 minutes [Olufsen:442, Landell:146]. When this practice was successful, it was often regarded as a result of the skills of the hairdresser. There are reports that some have even 10 to 20 corpses in their bodies.

The use of boiled, distilled or flowing water for consumption and daily needs was regarded as one of the most effective and easy way to combat this 
disease. In some cases, the rishta in the body did not show itself for up to 6 months. As a result, Europeans and visitors who came and lived in the area where the illnes was spread were forced to return to Bukhara and apply to local residents. The reason was that doctors and surgeons in the Turkestan General-Governorship did not know how to get rid of them. In the regions close to the ponds of the river, this disease was relatively less common, and after the introduction of the canalization system, it decreased significantly in Tashkent and other regions of Turkestan. Bisides, it was noted that it was not found in mountainous areas at all.

Another most common disease in the region was eye diseases. In desert zones, this disease was caused by dust. Olufsen, who resided in Bukhara Emirate, noted that one out of every 10 people in the emirate suffered from ophthalmology, a quarter of whom were blind [Olufsen:444]. Many could see badly, others had spots on the cornea, the eyelashes grew inside, or their eyes became inflamed. $\mathrm{H}$ Lansdell noted that the effects of sun and dust caused eye diseases [Lansdell :450]. Different methods were used to treat the eyes. Especially, local residents were able to use eye-catching medications and herbs to rinse eyes, wash them with grean tea leaves or warm milk and provide local pharmacists.

Olufsen noted that small pox epidemic that spread once in two years and bad hygiene of the population caused eye deseases. However, sources in the history of the region reject the spread of the desease in Bukhara every two years. Besides, since most of the population was Muslim and they performed ablution several times a day to hold daily prayers, it is clear that both of these reasons are implausible. However, another reason was that the population used stagnant water, which is believable. Because drinking and using steamed water without boiling caused rishta and other diseases. In addition, hot summer climate, weather conditions, high levels of light and salt dust were also the reasons of eye deseases. Furthermore, due to bad air circulation system in narrow streets of the city, wearing veils, not wearing headwears shadowing the eyes effected on eye diseases.

Most interestingly, people with blindness were busy with some activities. While some of them begged in the streets, many did not want to do so. They were 
involved in many jobs such as shampooers in the baths and massagers at home, which was considered one of the old ways to treat rheumatism. Some of them also worked in the workshops, and they were able to turn the workpiece into a rhythmic gear and perform a motor function. Most visually impaired people were been able to move freely on the streets and were well aware of their surroundings. Due to the arrival of Russian doctors and medical care in the country, eye diseases reduced.

One of the diseases that can be encountered in the region was small pox. However, no one was able to diagnose this disease. Nevertheless, in the fight against this disease, Arab medicine was used in traditional medicine. Another method of treatment was that the patient laid in bed at night and placed in front of the door or gate of his house.

External factors also existed in the distribution of various infectious diseases. One of them was caravans, with what cholera and measles appeared. In other words, caravans acted as distributors of diseases.

Another disease is a rash or leprosy that was found in almost all parts of Turkistan, Bukhara and Khiva. It was very contagious and the ill died because of the lack of treatment in the researched period. Therefore, these people lived in isolated areas separated from the population such as the edges of towns, their neighborhoods or streets and villages in remote areas. In particular, in the northeastern part of Bukhara, there was "Guzari pesyon (Leprosy quater)". Local, foreign, and Russian researchers noted that the ill were provided by donations or government-funded funds. They also had their own mosques, markets, baths, madrassas. Nevertheless, this sort of separation was sometimes unsuccessful. Because there was no prohibition if lepers begged in the streets, they also drifted into the densely populated areas of the city, and as a result, the disease spreaded to some extent. The illness was considered as a punishment by God, so this kind of illness was considered a cursed person [Olufsen: 445-446].

E. Schuyler showed leprosy as one of the most common ailments in the region. Pes and lepers were required to live in specially separated areas of the city, with their own markets and limited communication with others. However, as they 
begged, they went to sacred places and Schuyler wrote that he had seen them in Shohi Zinda complex [Schuyler: 148-149].

There was another skin disease in Tashkent and it was called local "sickness" by Russian. The local population was more likely to have an infection called Afghani ulcer or pasha khurda. This unpleasant disease developed in face or hands and expanded over time. Local doctors were very skilled in treating this illness, and Russian doctors learned to cure it. Schuyler wrote that a pharmacist friend's son was treated with lead vinegar and had no trace [Schuyler:149).

The study and analysis of books and sources written by European authors show that there were other deseases with their treatment in the area. For instance, tuberculosis (locally called lapsha), syphilis or zahm, goitre, plague that were observed in the area were treated by local medical servicemen.

\section{Conclusion}

To sum up, traditional medical experience and practices were widely used to prevent the spread of infectious deseases. The integration of local and modern medical skills and treatment methods decreased the number of victims considerably. Its is seen that local people and visitors applied for the both local and European treatment skills.

\section{List of Used Sources}

1. Annette M.B. Meakin In Russian Turkestan: A Garden of Asia and Its People // London, 1903. Pp. 316.

2. Azizov I. Rishta kasalligini davolash va oldini olish yullari // XIX - XX asr boshlarida Markaziy Osijoda intellektual meros: ananalar,va innovatsijalar ilmij andjumani tiuplami. 2018. P. 234

3. Eugine Schuyler. Turkistan: Notes of a Journey in Russian Turkistan, Kokand, Bukhara and Kuldja. New York. Scriber Armstrong \& Co. 1876. Pp.411.

4. Henry Lansdell. Russian Central Asia including Kuldja, Bukhara, Khiva and Merv // London. Vol. 1-2. 1885. Pp. 684.

5. Olusen O. The Emir of Bukhara and his Country // Nielsen \&Lydichf. (Axel Simmelkler) Copenhagen. 1911. Pp. 599.

6. Charles Marvin. Reconnoitering Central Asia // London. 1886. Pp. 421.

7. O'zbekiston hududida tabiiy fanlar yo'naliishidagi ilmiy tadqiqot va ekspeditsiyalar // Editor in Chief: D.Kh. Ziyaeva, (Rasulova D. V. Kholov. M. Yakubova, N. Karieva and others.). Tashkent, Akademnashr - 2019. 416 p.

8. Ziyaeva D. Kh. The Sources on the History of Intellectual Heritage of Uzbekistan (XIX the beginning of the XX centuries) // Adabiyot Uchqunlari. -T. Pp. 287. 
